\title{
Web-based protected geoinformation system of criminal analysis (RICAS) for analytical support for crimes investigation
}

\author{
Dmytro Uzlov \\ Head of Information Support and Police Coordination \\ Department of the Direktorate of National Police of \\ Ukraine in Kharkiv region \\ Kharkiv, Ukraine \\ poputcik@i.ua
}

\begin{abstract}
This article is devoted to the problem of appliance of web-based geoinformation tools for improving the effectiveness of information-analitical work in the internal affairs through the creation of intelligent technological tools of the new generation. It has gone the overview of foreign automated information and analytical works, highlighting their strengths and weaknesses. As a solution to the problems set forth proposed to use developed web-oriented protected geoinformation intelligent system of criminal analysis - RICAS for analytical support of crimes investigation. Its purpose, functionality, performance techniques criminal analysis means the system benefits compared with existing analogues and novelty are described.
\end{abstract}

Keywords - geoinformation system, crime analysis, the implicit connection, hidden patterns, unified display space, the visual analysis of the crime.

\section{INTRODUCTION}

The state of the art of the current IT solutions, especially network-based applications, in conjunction with developed mathematical models and processing methods for large amounts of heterogeneous and unstructured data (Big Data, Data Mining, Text Mining) provides ample opportunities for intellectualization and mass availability of solutions to numerous tasks. Among these are tasks pertaining to further automation and intellectualization of processing large amounts of data on crimes and criminals in the process of crime investigation. In the meantime, apart from with some local achievements, these activities have not acquired a system-wide and mass character as yet for various reasons.

The current state of the information and analytical support of the Internal Affairs authorities (IAA) of Ukraine has the following characteristic features:

1. The databases of the Internal Affairs authorities have accumulated a huge amount of data on criminally significant persons and events, which encompasses tens of millions of records; and their number increases daily.

2. This data is usually processed using simple operations with no use of knowledge-intensive methods and technologies, which makes it impossible to conduct an analytical analysis to identify any hidden or implicit links between the individuals and events in the large data sets available.

3. The analysis of requests that come to the divisions of the information and analytical support of the Internal Affairs authorities shows that most of them are requests for searching for crimes by analogy and persons who have

\author{
Volodymyr Strukov \\ Head of Information Technologies Department \\ of the Kharkiv National University of Internal Affairs \\ Kharkiv, Ukraine \\ struk_vm@ukr.net
}

committed similar crimes. The existing automated system for processing such requests (the integrated information retrieval system, IIRS) allows receiving lists, the sizes of which may sometimes amount to hundreds of crimes and thousands of persons. These lists are further processed manually. This procedure is quite complex and timeconsuming, depends on the qualification of the performer, is not automated, requires special skills of dealing with the IIRS, and therefore has the following key drawbacks:

1) An objectively low efficiency of manual processing of large text arrays;

2) A low probability of detecting eventual internal interrelations between the events and persons in the received large textual array;

3) An impossibility of identifying links between the elements of the received list (persons and events) and similar data that are not included in the above list or are explicitly or implicitly stored in other data sets of the system.

The above drawbacks are aggravated with time by the fact that the volumes of stored information are growing daily, being added with newly received data.

\section{ANALYSIS OF EXISTING SYSTEMS}

A review of the solutions available in this area has shown that abroad there are currently automated systems that can partially solve the described issues[7,8].

The $I 2$ system was developed by $I B M$ to handle analytical tasks of law-enforcement authorities. The system provides an opportunity to display the data available in the storage created under the $\mathrm{I} 2$ shell in the IBM product storage format on proprietary cards and perform data link analysis (Fig. 1).

The system has high hardware requirements, complexity in deployment and training, high cost and, most importantly, need to switch to data storage in proprietary formats. At the same time, the system does not provide any opportunity to associate a geographical space, time and event in a single visual space of display.

The CRIMEVIEW Server system is used in the police department of Glendale, California. It is based on the ESRI cartographic platform. The main principle is to analyze areas with the highest level of street crime. Patrol routes are designated for the identified areas. 
The My Neighborhood Map System system is used in Seattle (Waashington, USA). The main purpose is to visualize incoming messages about crimes and police reports.

The CRIMEDC system is used in the police department of the city of Washington. The main purpose is to provide the public with data on committed crimes.

Most of the systems reviewed offer solutions for informing the public and, what is crucially important is that they involve not the integration into the existing systems, but their installation as independent systems.

The purpose of the article. To deal with the above problems, a RICAS web-based secure crime analysis geographic information system for analytical support for crime investigation was developed and put into practical use. Its purpose, functionality, performance techniques criminal analysis means the system benefits compared with existing analogues and novelty are described in this article.

\section{COMPONENTS AND FEATURES OF RICAS}

The simplest approach for simulating pulsed traffic is to use the one order statistical characteristics. More exact results turn out in case of application of the second order statistical characteristics. They are usually created on the basis of correlative function, indexes of dispersion or the generalized measure of peakedness [11].

The system is intended to:

- Increase the effectiveness of the use of information records for the operative investigative activities of IAA officers, pretrial investigation, public order enforcement activities;

- Reduce the response time to incoming information about crimes and offenses, and, consequently, solve them more effectively in hot pursuit;

\section{- Anticipate and prevent crimes;}

- Provide an authorized access to system resources from any remote web client that has a secure communication link with the server;

- Improve the quality and timeliness of managerial decisions by managers at all levels of responsibility.

- The development of the system is based on the following factors:

- Any criminally significant information contains data on the scene of a criminal act, which can be reported either in text format as an address or in geographical values and time of commission;

- Any subject or object of crime is linked to geographical values in text format (registration address, residence address, company registered address, place of work, place of registration of vehicle, weapons, etc.);

- Criminal events, subjects and objects, as a rule, have interrelations in some parameters which are very difficult or impossible to be detected manually due to the large size of the data being processed;

- The maximum effect is achieved by applying jointly the automated procedures and methods of criminal analysis used by an expert analyst in the course of processing a particular event by analyzing the visual display in a single representation space.

Mathematical Support for the System. As a mathematical apparatus underlying the development of the system, Data Mining, Text Mining, Visual Mining, Link Analyzes, Big Data, Computational Intelligence technologies are used, the tools of which allow for the intellectual analysis of huge data sets accumulated in the police and other sources (the Internet, social networking websites) to identify hidden and implicit links between the individuals and events in them with the aim of forming versions for prevention and detection of crimes.

In this field the features of the initial data of criminal analysis were investigated and mathematical models of real-time data were proposed which provide an opportunity to apply classical methods of Data Mining and Text Mining for the intelligent processing of this data [1,2]. Algorithms for solving various purpose-oriented sub-tasks of criminal analysis, such as crime pattern analysis, general profile analysis, case analysis, comparative analysis, offender group analysis, specific profile analysis, investigation analysis were developed and adapted [4-6].

The developed algorithms provide the following operations to be performed with the input streams:

- Clustering of objects according to one or more features that have common spatiotemporal properties (Fig. 2);

- Automatic detection and visualization of street crime concentration areas according to one or more types (Fig. 3);

- Creation of a temporary event feed for a specific geographical location (a retrospective review of criminal events that occurred at a given time in the area of the scene of the event being investigated);

- Grouping of objects and subjects around the event;

- Analysis of the links of persons, objects, events in a given range (Fig. 4).

Software of the System. The software implementation of the system is completed as a webbased client-server system built on thin client technology. Each remote client application has an 
authorized access to the system with certain rights via a certified secure data link. The system provides access to video information received in real time from TRIOLAN video cameras installed in various locations in Kharkov, which makes it possible to observe the events occurring at a given time in definite locations in Kharkov.

The system is a multi-platform solution. The server and client applications are written using PHP, JavaScript, MySQL. The client applications run in iOS, Android, Windows, Linux.

OpenStreetMap is used as a platform for geoinformation tools of the system.

Outstanding Features. The RICAS system enables to perform operations of data analysis, processing and representation on a qualitatively new technological basis; the system is implemented as an add-on (shell) of the existing IIRS of Ukrainian IAA, and what is crucially important is that the system can be implemented without removing the old system or suspending its operation; and the system makes it possible to improve simply and smoothly its functionality and efficiency to a significant level.

RICAS is the first intelligent crime data analysis system that has combined in a single mapping space the main and most advanced methods and techniques for crime analysis and real-time analytical search, which significantly increases the efficiency and effectiveness of detecting crimes in hot pursuit and earlier undetected crimes.

Since the system is an add-on to the existing databases, it can display both explicitly specified links between individuals, and build visual links between individuals who at first sight are not related to each other. The system uses several algorithms to find links: a recursive search for the links of persons involved in different events, and a visual search for links. In the course of outputting structured information in a special way to the visual display environment, it is possible to establish links such as "Scene of crime - Accomplice - Criminal", "Crime Suspect - Accomplices".

\section{PRACTICAL EFFECT.}

The RICAS system was implemented in the practical activities of the police in 2016, tested in the Main Department of the National Police in Kharkov region and showed its effectiveness as a tool for identifying and investigating crimes (confirmed by assessments of European experts of the EU Consultation Mission during numerous presentations). About 800 crimes were solved during its testing by a group of trained expert analysts. The system is recommended by the experts from the EU Consultation Mission to be used as a nationwide platform for crime analytics.

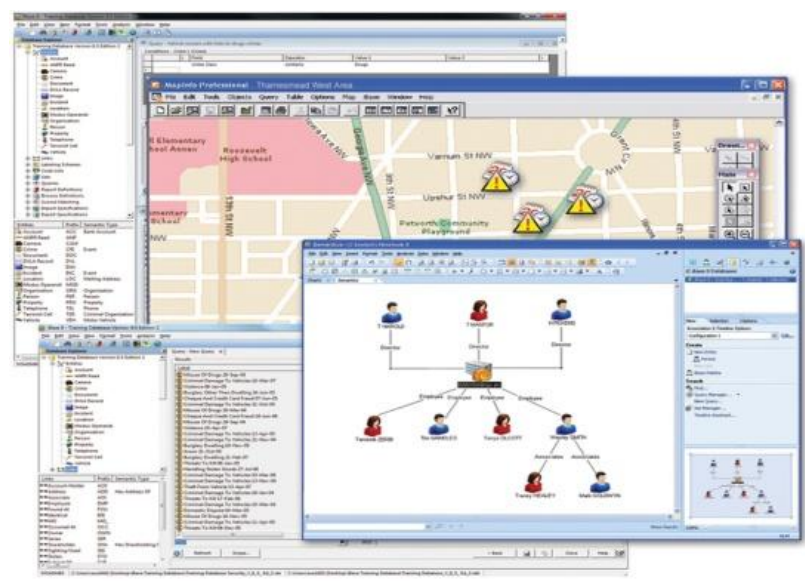

Fig. 1. Data link analysis in I2.

\section{REFERENCES}

[1] Bodyanskiy Ye.V., Strukov V.M., Uzlov D.Yu. Zadacha otsenki blizosti mnogomernykh obyektov analiza dannykh [The problem of evaluating the proximity of multidimensional objects of data analysis]. USiM, 2016, No.6, pp. 67-72.

[2] Bodyanskiy Ye.V., Strukov V.M., Uzlov D.Yu. Obobshchennaya metrika $v$ zadache analiza mnogomernykh dannykh s raznotipnymi priznakami [The generalized metric in the problem of analysis of multidimensional data with different types of characteristics ]. Zbirnyk naukovykh prats Kharkivskoho natsionalnoho universytetu Povitryanykh Syl [Collection of research papers of Kharkiv National University of Air Forces], 2017, Vypusk [Issue] 3(52), pp. 98-101.

[3] Lande D. V. Internetika: Navigatsiya v slozhnykh setyakh: modeli i algoritmy [Internetics: Navigation in complex networks: models and algorithms]. D. V. Lande, A. A. Snarskiy, I. V. Bezsudnov. M. Librokom (Editorial URSS), 2009, $264 \mathrm{p}$

[4] Uzlov D. Yu. Vykorystannya metodiv i modeley intelektualnoyi obrobky nestrukturovanoyi kryminalistychnoyi informatsiyi [Using methods and models of intellectual processing of unstructured criminalistic information]. D. Yu. Uzlov, Intelektualni systemy ta prykladna linhvistyka: materialy III Vseukr.yi nauk.-prakt. konf. [Intelligent Systems and Applied Linguistics: Materials of III Allukrainian sciences and pr. Conf.],Kharkiv : NTU KHPI, 2014, pp. 13-15.

[5] Uzlov D. Yu. Vykorystannya povedinkovoho profilyu dlya vyyavlennya oznak kiberzlochynnosti [Using the behavioral profile for detecting signs of cybercrime]. Dmytro Yuriyovych Uzlov. Vykorystannya innovatsiynykh tekhnolohiy u poperedzhenni zlochyniv : materialy nauk.-prakt. seminaru (m. Kharkiv, 6 hrud. 2012 r.) [Use of innovative technologies in the prevention of crimes: materials of sciences and pr. seminar]. MVS Ukrayiny, Kharkiv. nats. un-t vnutr. sprav, Kharkiv: KHNUVS, 2012, pp. 161-164.

[6] Uzlov D. Yu. Ispolzovaniye metoda komparatornoy identifikatsii dlya dinamicheskogo napolneniya tezaurusa operativno-rozysknoy deyatelnosti [Using the method of comparator identification for the dynamic filling of the thesaurus of operative investigative activities]. N. F. Khayrova, D. Yu. Uzlov, S.V. Petrasova. SkhidnoYevropeyskyy zhurnal peredovykh tekhnolohiy [East European Magazine of Advanced Technology], 2014, No. 3/2 (69), pp. 4-8.

[7] Manning C. D. Introduction to Information Retrieval / C. D. Manning, P. Raghavan, H. Schütze. - Cambridge : Cambridge University Press, 2008. -544 p.

[8] Westphal C. Data Mining for Intelligence, Fraud and Criminal Detection. Advanced Analytic \& Information Sharing Technologies / C. Westphal. - New York : CRC Press Taylor \& Francis Group, 2009. $-440 \mathrm{p}$ 


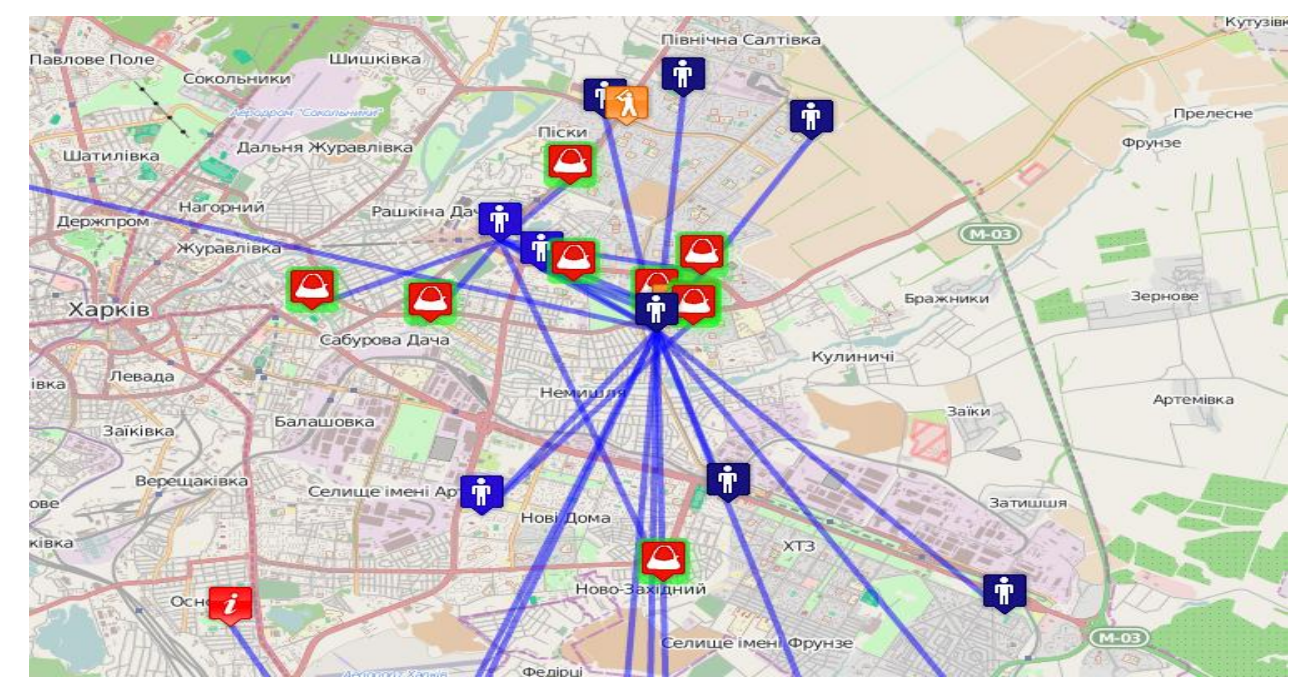

Fig. 2. Clustering of objects according to one or more features.

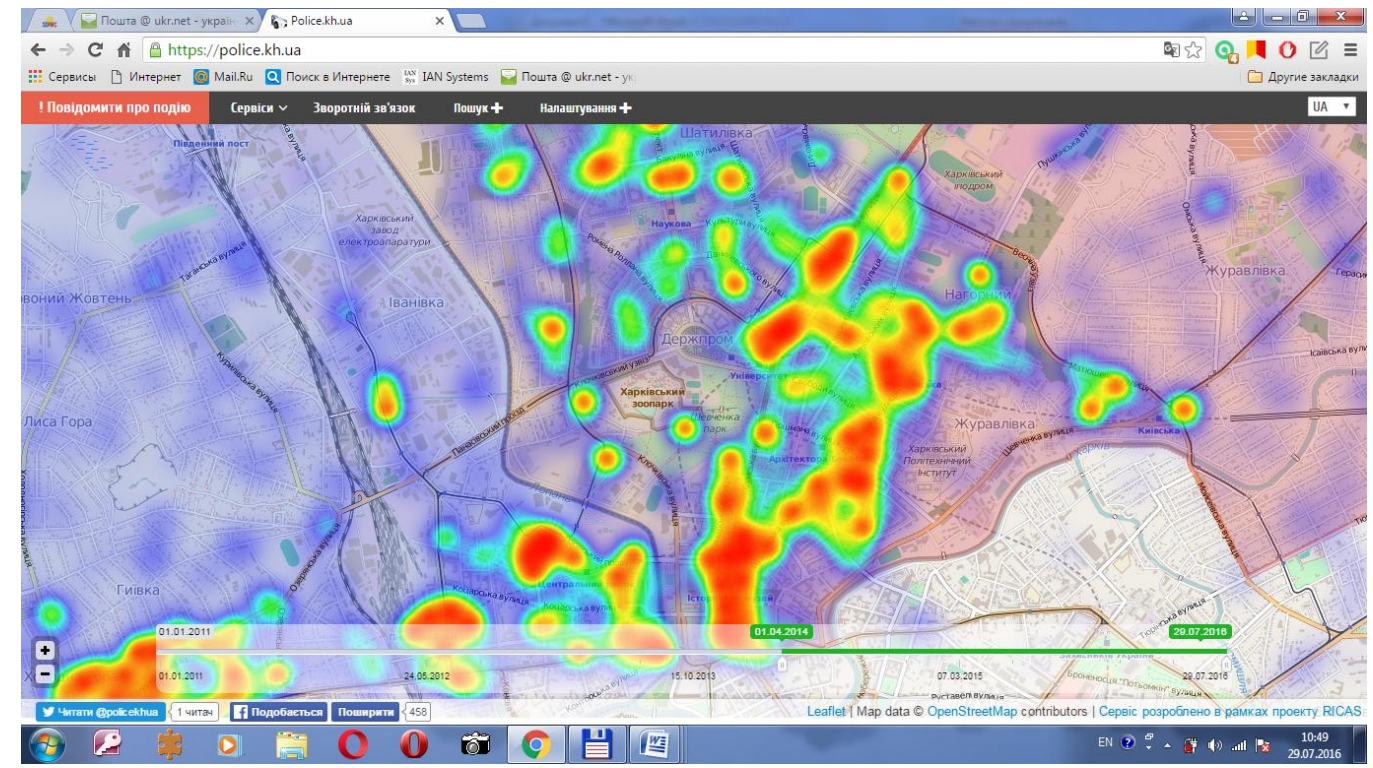

Fig. 3. Automatic detection and visualization of street crime concentration areas.

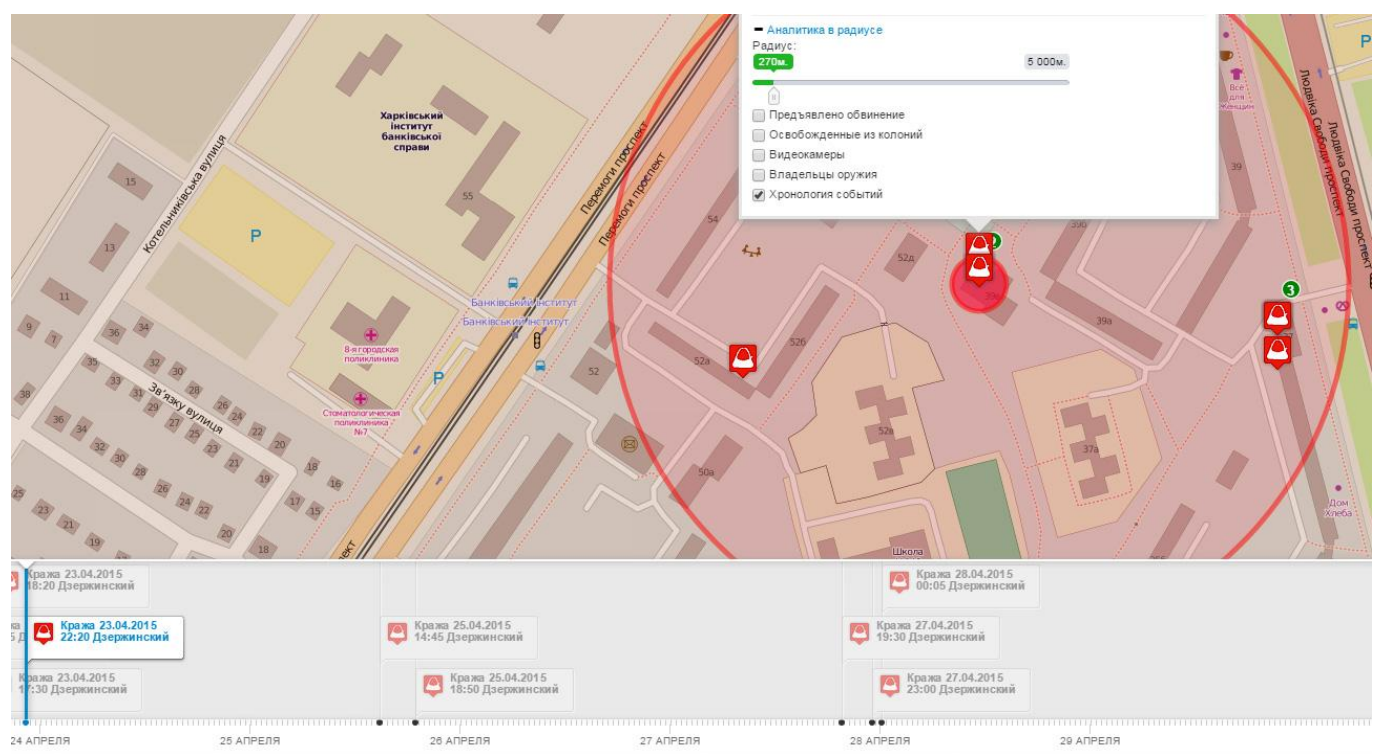

Fig. 4. Analysis of the links of persons, objects, events in a given range. 


Web-based protected geoinformation system of criminal
analysis (RICAS) for analytical support of crimes
investigation

geoinformation system, crime analysis, the implicit connection, hidden patterns, unified display space, the visual analysis of the crime

This article is devoted to the problem of appliance of weboriented geoinformation tools for improving the effectiveness of information-analitical work in the internal affairs. It has gone the overview of foreign automated information and analytical works. As a solution to the problems set forth proposed to use developed web-oriented protected geoinformation system of criminal analysis - RICAS for analytical support of crimes investigation. Its purpose, functionality, implementation features, benefits compared with existing analogues and novelty are described.
Веб-ориентированная защищенная геоинформационная система криминального анализа (RICAS) для аналитического сопровождения расследования преступлений

геоинформационная система, криминальный анализ, неявные связи, скрытые закономерности, единое пространство отображсения, визуальный анализ преступлений

В работе рассмотрена проблема применения вебориентированных геоинформачионных инструментариев для повышения эффективности информационно-аналитической работы в органах внутренних дел. Выполнен обзор зарубежных аналогов. $B$ качестве решения предложена разработанная веб-ориентированная защищценная геоинформационная система криминального анализа - RICAS для аналитического сопровождения расследования преступлений. Описаны её назначение, функииональные возможности, особенности реализации, преимущуества по сравнению с существующими аналогами и новизна.

\begin{tabular}{|c|c|c|c|c|c|c|}
\multicolumn{2}{|c|}{ Authors } \\
first name & last name & email & country & organization & $\begin{array}{c}\text { Web } \\
\text { page }\end{array}$ & $\begin{array}{c}\text { Corres- } \\
\text { ponding? }\end{array}$ \\
Dmitro & Uzlov & poputcik@i.ua & Ukraine & Direktorate of National Police of Ukraine in Kharkiv region \\
ker & - \\
Volodymyr & Strukov & struk_vm@ukr.net & Ukraine & Kharkiv National University of Internal Affairs & - \\
- & -
\end{tabular}

